\section{Storage effects on genomic DNA in rolled and mature coca leaves}

\author{
Emanuel L. Johnson, Soo-Hyung Kim, and Stephen D. Emche \\ USDA ARS Alternate Crops and Systems Laboratory, Beltsville, MD, USA
}

BioTechniques 35:310-316 (August 2003)

Rolled and mature leaf tissue was harvested from Erythroxylum coca var. coca Lam. (coca) to determine a method for storage that would maintain DNA with high quality and content up to 50 days. Harvesting coca leaf tissue under Andean field conditions often requires storage from 3 to 10 days before extraction where tissue integrity is lost. All samples of rolled and mature coca leaf tissue were harvested and separately stored fresh in RNAlater ${ }^{T M}$ for 50 days at $4^{\circ},-20^{\circ}$, and $23^{\circ} \mathrm{C}$, while similar samples were air-dried for $72 \mathrm{~h}$ at $23^{\circ} \mathrm{C}$ or ovendried for $72 \mathrm{~h}$ at $40^{\circ} \mathrm{C}$ after storage, before extraction. Triplicate samples of each tissue type were extracted for DNA at 10-day intervals and showed that DNA integrity and content were preserved in leaf tissue stored at $4^{\circ}$ and $-20^{\circ} \mathrm{C}$ for 50 days. Rolled and mature leaf tissue stored at $4^{\circ},-20^{\circ}$, and $23^{\circ} \mathrm{C}$ showed insignificant degradation of DNA after 10 days, and by day 50, only leaf tissue stored at $4^{\circ}$ and $-20^{\circ} \mathrm{C}$ had not significantly degraded. All air-and oven-dried leaf tissue extracts showed degradation upon drying (day 0) and continuous degradation up to day 50, despite storage conditions. Amplified fragment length polymorphism analysis of DNA from rolled and mature leaf tissue of coca stored at $4^{\circ}$ and $-20^{\circ} \mathrm{C}$ for 0,10 , and 50 days showed that DNA integrity and content were preserved. We recommend that freshly harvested rolled or mature coca leaf tissue be stored at $4^{\circ},-20^{\circ}$, and $23^{\circ} \mathrm{C}$ for 10 days after harvest, and if a longer storage is required, then store at $4^{\circ}$ or $-20^{\circ} \mathrm{C}$.

\section{INTRODUCTION}

Research in our laboratory requires the extraction and isolation of genomic, mitochondrial, and chloroplast DNA from leaf tissue of several drug crop plants to determine inter- and-intravarietal differences among and within taxons. Many of the taxons under investigation are indigenous to tropical environments and pose the problem of maintaining high-quality RNA and DNA during specimen collection and transportation. This is particularly true for taxa of Erythroxylum where the obstacles demarcated by Plowman and Rivier (1) still exist today. Several methodologies are available that address the preservation of plant material for molecular systematic studies for plants indigenous to tropical regions (2-6) as well as descriptions of their performance $(5,7,8)$. The most efficient method for preserving plant material is with the use of liquid nitrogen, but this imposes inherent problems in tropical environments (2).

The genus Erythroxylum, which comprises 240 species, has four cultivated taxons (Erythroxylum coca var. coca Lam; Erythroxylum coca var. ipadu Plowman; Erythroxylum novogranatense var. novogranatense [Morris] Hieron; Erythroxylum novogranatense var. truxillense [Rusby] Plowman) and is purported to contain many of the secondary allelochemicals found in Solanaceae (9). In addition, there are high contents of polyphenols in the leaf tissue (unpublished data); thus, during extraction, DNA is subjected to binding and degradation by these terpenoids and tannins (10). The difficulty of isolating high-quality RNA and DNA from highly phenolic plant tissue was reported by Katterman and Shattuck (11) and from recalcitrant plant tissue by Baker et al. (12). In Gossypium hirsutum of Malvaceae and the related family Bombacaceae, both phenolic terpenoids and tannins have been shown to bind to RNA and DNA after cell lysis, causing their degradation (10). Once combined with RNA or DNA, the phenolics cannot be removed by conventional extraction procedures, rendering them useless for in vitro translation or cDNA cloning studies (10). It has been shown that RNAlater ${ }^{\mathrm{TM}}$ successfully preserves RNA in plant tissue (13), and in this study we investigated whether it would also preserve DNA. To circumvent interference caused by polyphenolic terpenoids and tannins, highly alkaline $\mathrm{pH}$ buffering and polyvinylpolypyrrolidone (PVPP) were used in this study, which through hydrogen bonding sequestered the phenolics and tannins, therefore efficiently removing them from the leaf tissue homogenate as previously described $(10,14,15)$. In a previous study, we successfully differentiated the Erythroxylum taxa using amplified fragmentlength polymorphism (AFLP) DNA analysis (16). The purpose of this study was to find a method of storage for $E$. $c$. var. coca leaf tissue so that the content and integrity of the DNA of interest would be preserved so that it would be useful for future interspecific, intraspecific, and related DNA studies.

\section{MATERIALS AND METHODS}

\section{Harvest and Storage of Leaf Tissue}

Rolled $(<10$ days old from bud break; immature) and mature ( $>30$ days old) leaf tissue of $E$. c. var. coca Lam. grown under greenhouse conditions at Beltsville Agricultural Research Center (Beltsville, MD, USA) (17) were separately harvested and stored at $0^{\circ} \mathrm{C}$. A portion of rolled and mature leaves ( 3 samples/leaf type/storage condition) were extracted for genomic DNA (total DNA) using a DNeasy ${ }^{\mathrm{TM}}$ Plant Mini Kit (Qiagen, Valencia, CA, USA; procedures described below) and reported as day 0 . All other rolled and mature leaves (4 and 2 leaves/tube, respectively) were separately submerged in 3.5 mL RNAlater (Ambion, Austin, TX, USA) in polyethylene tubes and stored up to day 50 after harvest under the following conditions: $23^{\circ} \mathrm{C}$ (room temperature) $; 4^{\circ} \mathrm{C} ;-20^{\circ} \mathrm{C} ; 23^{\circ} \mathrm{C}$, oven-dried for $72 \mathrm{~h}$ at $40^{\circ} \mathrm{C}$ before extraction; and $23^{\circ} \mathrm{C}$, air-dried for $72 \mathrm{~h}$ at $23^{\circ} \mathrm{C}$ before extraction. Rolled and mature leaves (3 sample replicates/storage condition) were removed on days $0,10,20,30,40$, and 50 and extracted to determine DNA content and quality. 
Table 1. Sequences of Primers Used for Selective Amplification of $4^{\circ},-20^{\circ}$, and $23^{\circ} \mathrm{C}\left(0-, \mathbf{1 0}^{-}\right.$, and 50 Day) Samples

\begin{tabular}{|ccc|}
\hline $\begin{array}{c}\text { Primer } \\
\text { Pair }\end{array}$ & $\begin{array}{c}\text { Forward Primer } \\
\text { (EcoRI) }\end{array}$ & $\begin{array}{c}\text { Reverse Primer } \\
\text { (Msel) }\end{array}$ \\
\hline 1 & $5^{\prime}$-D4-GACTGCGTACCAATTCACT-3' & 5'-GATGAGTCCTGAGTAACAT-3' \\
2 & $5^{\prime}$-D4-GACTGCGTACCAATTCACA-3' & 5'-GATGAGTCCTGAGTAACAA-3' \\
3 & $5^{\prime}$-D2-GACTGCGTACCAATTCAAC-3' & $5^{\prime}$-GATGAGTCCTGAGTAACAC-3' \\
4 & $5^{\prime}$-D3-GACTGCGTACCAATTCAAG-3' & 5'-GATGAGTCCTGAGTAACTA-3' \\
5 & $5^{\prime}$-D4-GACTGCGTACCAATTCACC-3' & 5'-GATGAGTCCTGAGTAACTA-3'
\end{tabular}

Unique sequences and dyes are shown in bold type.

\section{Isolation of DNA from Leaf Tissue}

All DNA was isolated using the DNeasy Plant Mini kit protocol with the following exceptions: (i) $10 \mathrm{mg}$ PVPP (high molecular weight cross-linked; Sigma St. Louis, MO, USA) were added into lysing matrix tubes (QBiogene, Carlsbad, CA, USA) before sample homogenization; (ii) two $0.53-\mathrm{cm}$ ceramic spheres (QBiogene) were added into lysing matrix tubes before sample homogenization; and (iii) sample homogenization was performed using a FastPrep $^{\mathrm{TM}}$ FP120 Instrument (Savant Instruments, Holbrook, NY, USA) at a speed setting of 6.5 for $45 \mathrm{~s}$.

\section{UV/Fluorimetry Quantitation}

Quantitation was performed with both UV (260/280 ratio; Beckman DU 530, Beckman Coulter, Fullerton, CA, USA) and fluorescence (PicoGreen ${ }^{\circledR}$ dsDNA quantitation kit; Molecular Probes, Eugene, OR, USA) on a Fluoroskan Ascent (Thermo Labsystems, Franklin, MA, USA) fluorimeter in a 96well platform plate (Greiner Bio-One, Longwood, FL, USA). Fluorescence analysis provided data of higher integrity and therefore was used for all sample quantitation. A standard curve was generated from DNA standards (PicoGreen kit) ranging from 1 to $500 \mathrm{ng} / \mathrm{mL}$, and final sample dilutions were 1:800. All measurements were repeated three times.

\section{Amplified Fragment-Length Polymorphism}

DNA fragments were amplified using the procedure by Vos et al. (18) modified as follows. Template DNA (500 ng) of 0-, 10-, and 50-day samples were digested by EcoRI and MseI (New England Biolabs, Beverly, MA, USA) and ligated to commercial EcoRI and MseI oligonucleotide adapters (Applied Biosystems, Foster City, CA, USA) in a single step, with incubation overnight at room temperature. Solutions were prepared as described previously, except as noted below $(19,20)$.

The preselective amplification of the restricted and ligated fragments utilized commercial EcoRI and MseI AFLP preselective primers and AFLP core mixture (Applied Biosystems). The thermal cycling program for this amplification was $94^{\circ} \mathrm{C}$ for $3 \mathrm{~min}$, followed by $20 \mathrm{cy}-$ cles of $94^{\circ} \mathrm{C}$ for $20 \mathrm{~s}, 56^{\circ} \mathrm{C}$ for $30 \mathrm{~s}$, and $72^{\circ} \mathrm{C}$ for $2 \mathrm{~min}$, with a final hold at $60^{\circ} \mathrm{C}$ for 30 min (GeneAmp ${ }^{\circledR} 9700$ PCR system; Applied Biosystems). The products from the preselective amplification were diluted as described previously $(19,20)$ and used as templates for the selective amplification. For the selective amplification, custom primers (Table 1) were used, with a WellRED ${ }^{\mathrm{TM}}$ active ester dye (D1, D2, or D4) added to the $5^{\prime}$ end of each EcoRI primer (Research Genetics, Huntsville, AL, USA). No modifications were made to the MseI primers. The labeled EcoRI primer was included at $0.05 \mu \mathrm{M}$, and the unlabeled MseI primer was included at $0.1 \mu \mathrm{M}$. The thermal cycling profile was $94^{\circ} \mathrm{C}$ for 2 min, followed by 10 cycles of $94^{\circ} \mathrm{C}$ for $20 \mathrm{~s}, 1^{\circ} \mathrm{C} /$ cycle stepdown of annealing temperature from $66^{\circ} \mathrm{C}$, held for $30 \mathrm{~s}$, and $72^{\circ} \mathrm{C}$ for $2 \mathrm{~min}$. This was followed by 25 cycles of $94^{\circ} \mathrm{C}$ for $20 \mathrm{~s}, 56^{\circ} \mathrm{C}$ for $30 \mathrm{~s}$, and $72^{\circ} \mathrm{C}$ for $2 \mathrm{~min}$, with a final hold of $60^{\circ} \mathrm{C}$ for $30 \mathrm{~min}$.
Samples were prepared for analysis by diluting the final amplified product 1:30 (v/v) in commercial Sample Loading Solution, which included 1\% (v/v) 400-bp DNA size standards (both from Beckman Coulter). Fragment separation and detection were performed by a genetic analysis system (CEQ 8000 ${ }^{\mathrm{TM}}$; Beckman Coulter); this used capillary electrophoresis on each sample, beginning with a 30 -s electrophoretic injection at $2 \mathrm{kV}$ and $35 \mathrm{~min}$ separation at $50^{\circ} \mathrm{C}$ and $6 \mathrm{kV}$.

\section{Statistical Analyses}

Analysis of variance was used to determine the effects of leaf tissue, storage temperature, storage treatment, and different storage days using SAS PROC GLM (SAS system for windows release 8.02; SAS Institute, Cary, NC, USA). Orthogonal contrasts were constructed to test various hypotheses assessing the effects of various treatment combinations at selected days of storage (10 and 50 days). The hypotheses tested using the orthogonal contrasts were $(i)$ leaf tissue, whether rolled or mature, does not have impact on genomic DNA content (rolled vs. mature); (ii) post-storage treatment does not alter the genomic DNA content at $23^{\circ} \mathrm{C}$ (dry vs. no-dry at $23^{\circ} \mathrm{C}$ ); (iii) low-temperature storage $\left(-20^{\circ}\right.$ and $\left.4^{\circ} \mathrm{C}\right)$ has no effect on DNA content when stored in RNAlater with no post-storage drying (low temperature vs. $23^{\circ} \mathrm{C}$ ); (iv) two different post-storage drying methods do not affect the DNA content (air dry vs. oven dry); $(v)$ the storage temperatures of $-20^{\circ}$ and $4^{\circ} \mathrm{C}$ lead to no difference in DNA content $\left(-20^{\circ}\right.$ vs. $\left.4^{\circ} \mathrm{C}\right)$; (vi) the effect of post-storage drying is the same for different leaf tissues (leaf tissue and poststorage drying interaction); and (vii) the effect of temperature treatments is the same for different leaf tissues (leaf tissue and temperature interaction).

\section{RESULTS AND DISCUSSION}

\section{DNA Content in Leaf Tissue during Storage}

In a preliminary experiment, we pur- 
chased and tested several commercially available plant designated DNA extraction kits to determine their efficiency, consistency, and repeatability in extracting the highest content and quality of genomic DNA from fresh, air-dried, and oven-dried leaf tissue of E. c. var. coca Lam. (unpublished data). The most effectual and reliable plant DNA extraction kit was the DNeasy Plant Mini kit from Qiagen. We also observed that the content of DNA extracted from freshly harvested rolled and mature leaf tissue of $E$. c. var. coca differed by 4-fold (unpublished data); therefore, both leaf types were used in the current study. This procedure would ensure that the DNA content and quality of both rolled and mature, as well as air- and ovendried E. c. var. coca leaf tissue, would be known. All subsequent DNA data and results reported in the current study were obtained with the DNeasy kit.

Figure 1, A-D, shows the data for rolled and mature leaf tissue of $E$. $c$. var. coca that were harvested and stored for 50 days. As previously observed, there was a 4-fold difference between the content of DNA in freshly harvested, rolled, and mature coca leaf tissue, which may be attributed to leaf age. From day 0 to day 10 of storage, there was no significant change in DNA content in rolled leaf tissue stored at $-20^{\circ}$ and $23^{\circ} \mathrm{C}$; however, DNA in rolled leaf tissue stored at $4^{\circ} \mathrm{C}$ on day 10 was significantly different (Figure 1A). We attribute this difference to DNA condensation, which is also prevalent in mature leaf tissue on day 10 (Figure 1, A and B). Rolled leaf tissue stored at $4^{\circ}$ and $-20^{\circ} \mathrm{C}$ showed minimal DNA loss at day 10 and remained static from day 30 through day 50 of storage $(2.7 \mu \mathrm{g} / 50 \mathrm{mg}$ dry weight and $2.4 \mu \mathrm{g} / 50 \mathrm{mg}$ dry weight, respectively; Figure 1A). From day 0 through day 50 of storage in rolled leaf tissue, there was a $3 \%$ decrease in DNA content in tissue stored at $4{ }^{\circ} \mathrm{C}$ and a $14 \%$ decrease in tissue stored at $-20^{\circ} \mathrm{C}$ (Figure 1A). DNA content in rolled leaf tissue stored at $23^{\circ} \mathrm{C}$ did not differ significantly from day 0 to day 10 of harvest, where its content was $2.6 \mu \mathrm{g} / 50 \mathrm{mg}$ dry weight leaf tissue, exhibiting only a $7 \%$ decrease (Figure 1A). By day 20 of storage, the content decreased by $67 \%$ and on day 50 of storage, DNA content in

Table 2. AFLP Analyses Using DNA Leaf Extracts of Rolled and Mature $E$. $c$. var. coca Leaf for 0, 10, and 50 Days

\begin{tabular}{|c|c|c|c|c|c|c|}
\hline & \multicolumn{3}{|c|}{ Rolled } & \multicolumn{3}{|c|}{ Mature } \\
\hline & 0 & 10 & 50 & 0 & 10 & 50 \\
\hline $4^{\circ} \mathrm{C}$ & + & + & + & + & + & + \\
\hline $23^{\circ} \mathrm{C}$ & + & + & + & + & + & + \\
\hline$-20^{\circ} \mathrm{C}$ & + & + & + & + & + & + \\
\hline
\end{tabular}

A + sign indicates successful amplified fragment-length polymorphism (AFLP) and fragment analysis. Only $4^{\circ}, 23^{\circ}$, and $-20^{\circ} \mathrm{C}$ samples were analyzed, as air and oven drying proved impractical for maintaining DNA integrity. Although the $23^{\circ} \mathrm{C}$ samples stored for 50 days showed extensive degradation, DNA integrity was sufficient for AFLP analysis. However, the quality of the fragment data was sub-par compared with the $4^{\circ}$ and $-20^{\circ} \mathrm{C}$ samples.

rolled leaf tissue stored at $23^{\circ} \mathrm{C}$ had declined to $0.74 \mu \mathrm{g} / 50 \mathrm{mg}$ dry weight, a $74 \%$ loss (Figure 1A).

The DNA content in mature leaf tissue of $E$. c. var. coca stored at $4^{\circ} \mathrm{C}$, from day 0 to day 10 , increased from 0.69 $\mu \mathrm{g} / 50 \mathrm{mg}$ dry weight leaf tissue to 1 $\mu \mathrm{g} / 50 \mathrm{mg}$ dry weight leaf tissue and re- mained static up to day 20 (Figure 1B). After day 20 of storage, DNA content in mature leaf tissue $\left(4^{\circ} \mathrm{C}\right)$ decreased to a low of $0.52 \mu \mathrm{g} / 50 \mathrm{mg}$ dry weight leaf tissue (day 30), increasing again to 0.77 $\mu \mathrm{g} / 50 \mathrm{mg}$ dry weight leaf tissue at day 50 (Figure 1B), exhibiting essentially no loss in DNA content from day 0. DNA

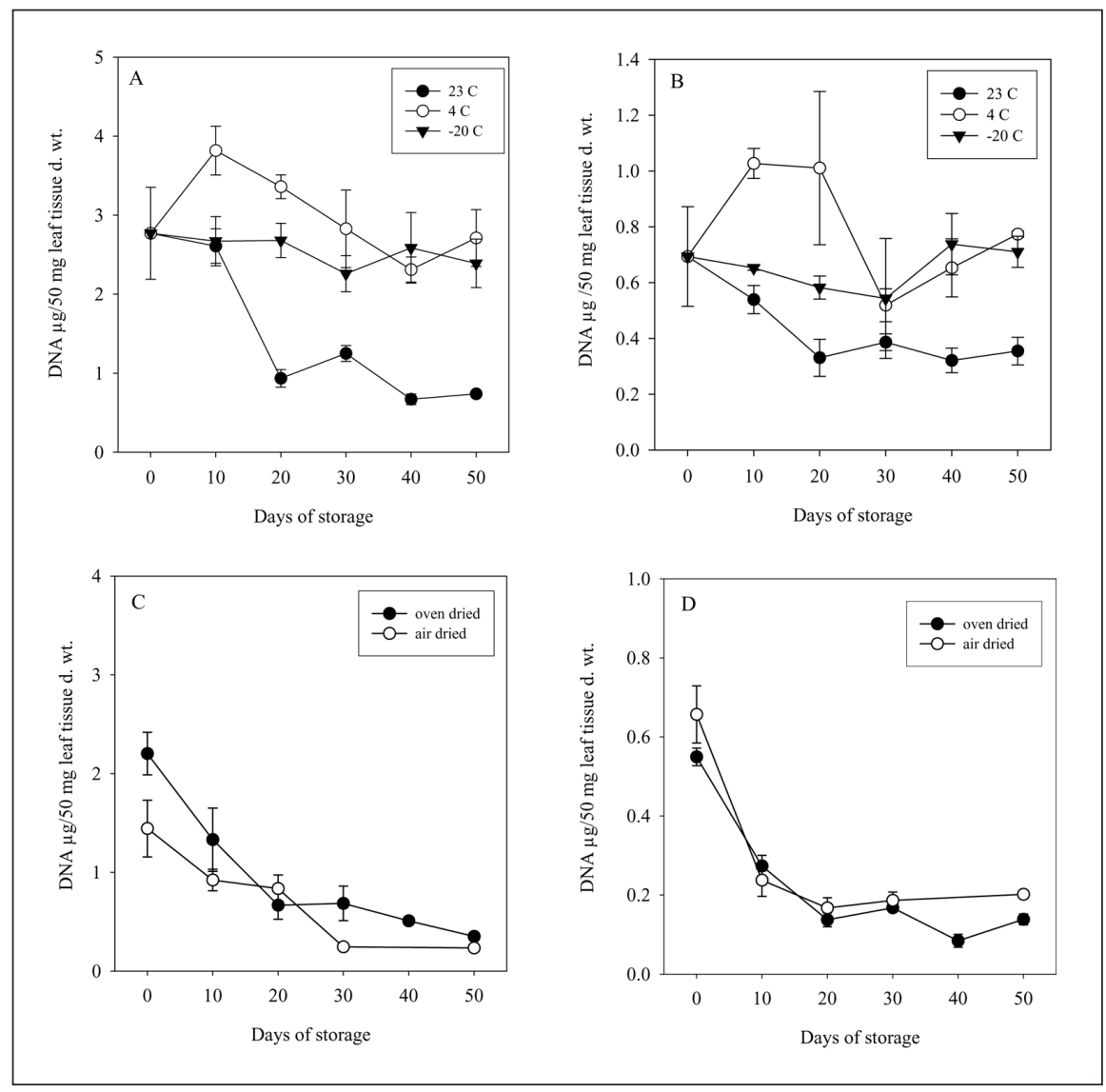

Figure 1. Storage effects on genomic DNA integrity in rolled and mature $E$. $c$. var. coca leaf tissue extracts. DNA integrity as a function of storage parameters over 50 days in (A) rolled, (B) mature, (C) rolled oven-/air-dried, and (D) mature oven-/air-dried. 
Table 3. Orthogonal Contrasts Testing Hypotheses of Interest

\begin{tabular}{|c|c|c|}
\hline \multirow[b]{2}{*}{ Orthogonal Contrast } & \multicolumn{2}{|c|}{$P>\mathrm{F}$} \\
\hline & Day 10 & Day 50 \\
\hline 1. Rolled vs. mature & *** & *** \\
\hline 2. Dry vs. no-dry at $23^{\circ} \mathrm{C}$ & *** & * \\
\hline 3. Low temperature vs. $23^{\circ} \mathrm{C}$ & 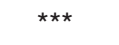 & 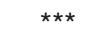 \\
\hline 4. Air dry vs. oven dry & ns & ns \\
\hline 5. $-20^{\circ}$ vs. $4^{\circ} \mathrm{C}$ & $\star \star * *$ & ns \\
\hline 6. Interaction $\left(1{ }^{*} 2\right)$ & $\star * *$ & ns \\
\hline 7. Interaction $(1 * 3)$ & ns & *** \\
\hline $\begin{array}{l}\text { ns, not significant } \\
{ }^{\star} \text { Significant at the } 0.05 \text { level } \\
{ }^{\star \star *} \text { Significant at the } 0.001 \text { leve }\end{array}$ & & \\
\hline
\end{tabular}

content in mature $E$. $c$. var. coca leaf tissue stored at $-20^{\circ} \mathrm{C}$ declined to a low of $0.54 \mu \mathrm{g} / 50 \mathrm{mg}$ dry weight leaf tissue at day 30 , increased to $0.74 \mu \mathrm{g} / 50 \mathrm{mg}$ dry weight leaf tissue at day 40 and remained static up to day 50 of storage, again resulting in no loss in DNA content (Figure 1B). By day 20 of storage mature $E$. $c$. var. coca leaf tissue stored at $23^{\circ} \mathrm{C}$ declined to a low of $0.32 \mu \mathrm{g} / 50$ mg dry weight leaf tissue and remained static through day 50, showing a 49\% loss in DNA content (Figure 1B). Figure 2 depicts the quality of extracted DNA in both rolled and mature $E$. $c$. var. coca leaf tissue at 0,10 , and 50 days of storage for $4^{\circ},-20^{\circ}$, and $23^{\circ} \mathrm{C}$ treatments. DNA qualitative results (Figure 1, A and B) mimicked the quantitative results for both rolled and mature leaf tissue, in that $4^{\circ}$ and $-20^{\circ} \mathrm{C}$ samples showed minimal degradation over 50 days, while $23^{\circ} \mathrm{C}$ exhibited some breakdown after 10 days and extensive degradation after 50 days (Figure 2). However, quantitative results are not always indicative of DNA quality.

The effect of air $\left(23^{\circ} \mathrm{C}\right)$ and oven drying $\left(40^{\circ} \mathrm{C}\right)$ on DNA content are shown in Figures 1 and 2. Through the first 10 days of storage DNA content in rolled, oven-dried, and air-dried leaf tissue declined to 1.3 (41\% loss) and $0.92 \mu \mathrm{g} / 50 \mathrm{mg}$ dry weight leaf tissue (36\% loss), respectively (Figure 1C). Both air- and ovendried tissue continued a gradual decline in DNA content where at day 50 contents were $0.23(84 \%$ loss $)$ and 0.35 $\mu \mathrm{g} / 50 \mathrm{mg}$ dry weight leaf tissue $(84 \%$ loss), respectively. By day 10 of storage in mature, air-dried, and oven-dried leaf tissue, DNA content was 0.24 and $0.27 \mu \mathrm{g} / 50 \mathrm{mg}$ dry weight leaf tissue and by day 50 had declined to 0.20 and $0.14 \mu \mathrm{g} / 50 \mathrm{mg}$ dry weight leaf tissue, a $70 \%$ and $75 \%$ loss, respectively (Figure 1D). Quality of DNA was also sacrificed by the drying methods (Figure 2). While 50-day rolled and mature dried samples exhibited less DNA quantitatively than 0-day samples, qualitatively

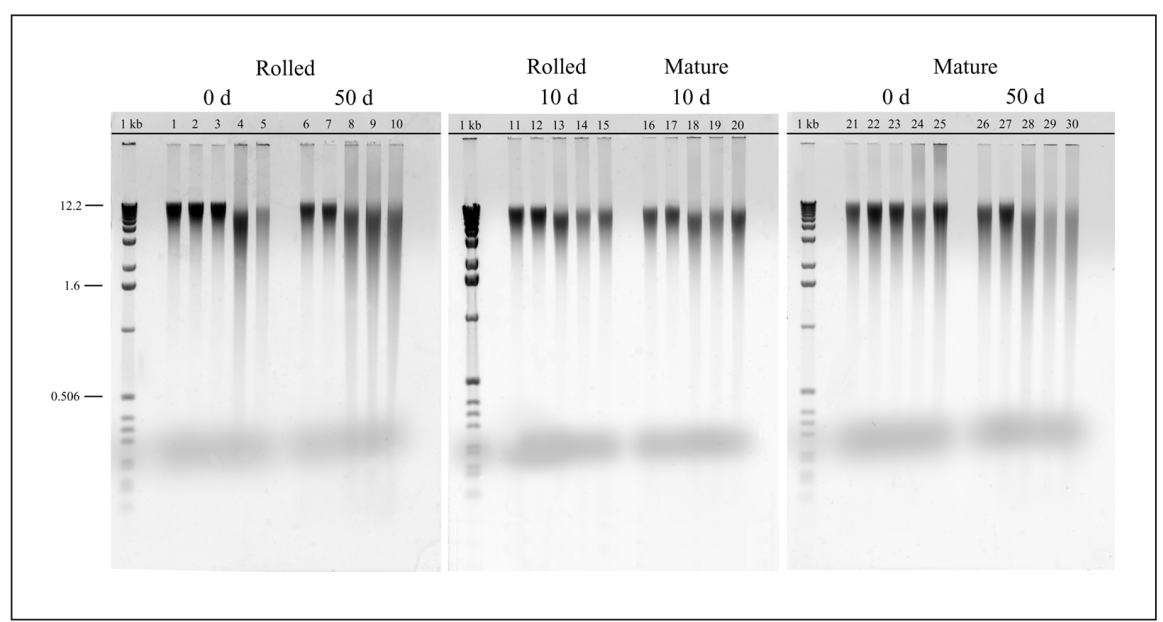

Figure 2. Gel electrophoresis (1\% agarose gel) of genomic DNA (150 ng/lane) from rolled and mature leaf tissue extracts of $E$. $c$. var. coca harvested and stored in RNAlater for 0,10 , and 50 days. Samples are as follows: lanes $1,6,11,16,21$, and $26,4^{\circ} \mathrm{C}$ samples; lanes $2,7,12,17,22$, and $27,-20^{\circ} \mathrm{C}$ samples; lanes $3,8,13,18,23$, and $28,23^{\circ} \mathrm{C}$ samples; lanes $4,9,14,19,24$, and 29 , oven-dried samples; and lanes $5,10,15,20,25$, and 30 , air-dried samples. d, days. there was little DNA degradation over 50 days of storage, beyond what was degraded during the initial drying process. We do not recommend the use of air or oven drying for E. c. var. coca leaf tissue for DNA studies because the time required for degradation is ephemeral and the amount and quality of DNA extracted are less than desired (Figure 1, C and D, and Figure 2).

DNA from rolled and mature leaf tissue stored for 0,10 , and 50 days was tested for integrity by AFLP analysis (see Materials and Methods section) with the five primer sets listed in Table 1. Table 2 shows the results of the AFLP analyses of DNA from rolled and mature leaf tissue stored for 0,10 , and 50 days. It is noteworthy that the quality of the DNA from all stored tissue types tested was sufficient for AFLP analyses.

We attribute the differences observed in DNA quality and quantity within $E$. c. var. coca leaf tissue to the conditions under which the leaf tissue was treated (Figures 1 and 2). Rolled leaf tissue $\left(4^{\circ}\right.$ and $\left.-20^{\circ} \mathrm{C}\right)$ maintained the highest DNA content and quality throughout the study, while all treatments of mature leaf tissue of $E$. $c$. var. coca had lower quantities of DNA before and during storage (Figures 1 and $2)$. The increase observed in DNA content between day 0 and day 10 in rolled and mature leaf tissue stored at $4^{\circ} \mathrm{C}$ is probably due to condensation as suggested by several researchers (E.L.J., personal communications). They summarized that it was not uncommon to observe an increase in DNA content in leaf tissue over the first several days of storage (E.L.J., personal communication), and their suggestions apparently are merited because there was not an increase in DNA content of this magnitude during the duration of the study (Figure 1, A-D).

For the current research, we did not label each leaf type from bud break to maturity, nor did we use leaf tissue from individual plants of the taxon, which would have been more definitive for DNA in terms of content and interspecific variation. This technique may have circumvented some of the variations that are known to exist within the taxon. Our desire was to mimic harvest of the two E. c. var. coca leaf 
tissue types that would occur if samples were collected under field conditions so that DNA obtained would thus be reflective of the storage. We have designed future research that will address these differences.

\section{Statistical Analyses}

The analyses breaking down the effects of storage temperature and poststorage drying have been performed using orthogonal contrasts (Table 3). The orthogonal contrast at 10 and 50 days of storage revealed that the hypothesis that rolled and mature leaf tissue contained the same DNA content should be rejected, verifying that rolled leaves contained higher DNA content than mature leaves (contrast 1). Post-storage drying decreased DNA content on both days (contrast 2). Low-temperature ($20^{\circ}$ and $4^{\circ} \mathrm{C}$ ) storage resulted in higher DNA content than room temperature $\left(23^{\circ} \mathrm{C}\right)$ at both days of storage (contrast $3)$. There was no difference in DNA content between air- and oven-dried samples at either of the storage days (contrast 4). Storage at $4^{\circ} \mathrm{C}$ resulted in higher DNA content than $-20^{\circ} \mathrm{C}$ at 10 days of storage, whereas no difference was found at 50 days of storage (contrast 5). Reduction in DNA content due to post-storage drying was more pronounced for rolled leaves than mature leaves at 10 days of storage $(P<0.01)$, while no such interaction was detected at 50 days of storage $(P=0.334)$ (contrast 6). There was no interaction between leaf age and low-temperature storage at 10 days of storage $(P=$ $0.321)$. However, storing at low temperature preserved DNA markedly more for rolled leaves than mature leaves at 50 days of storage $(P<0.001)$ (contrast 7).

\section{CONCLUSION}

This research demonstrates how the content of DNA differs within two developmental stages of $E$. c. var. coca leaf tissue, in terms of storage and preservation in RNAlater. Higher content and quality DNA was present in rolled leaf tissue that persisted from the first harvest (day 0) to 50 days of storage. The ideal temperature for storage of
E. c. var. coca leaf tissue that will maintain high-quality DNA and content for 50 days was found to be $4^{\circ}$ and $-20^{\circ} \mathrm{C}$. However, rolled leaf tissue of E. c. var. coca stored at $23^{\circ} \mathrm{C}$ will also provide DNA with sufficient content and quality when stored for 10 days or less. Therefore, the content and quality of DNA in rolled leaves of E. c. var. coca harvested in tropical regions and immediately stored in RNAlater should not be affected for the first 10 days of storage. The major advantages of this method for storing E. c. var. coca leaf tissue for DNA studies is $(i)$ it is convenient and portable; (ii) it may be stored without refrigeration up to 10 days after harvest; (iii) it can be stored up to 50 days at $4^{\circ}$ or $-20^{\circ} \mathrm{C}$ while maintaining high-quality DNA and RNA; (iv) it is cost-effective in terms of leaf tissue transport and equipment; and $(v)$ it maintains the quality of the DNA sufficiently enough (and without PCR inhibitors) to run successful AFLP analyses.

\section{ACKNOWLEDGMENTS}

Commercial products are listed for the reader's convenience only and indicate neither endorsement by the U.S. Department of Agriculture Research Service, nor criticism of similar products not mentioned.

\section{REFERENCES}

1.Plowman, T. and L. Rivier. 1983. Cocaine and cinnamoylcocaine content of Erythroxylum species. Ann. Bot. 51:641-659.

2.Chase, M.W. and H.H. Hills. 1991. Silica gel: an ideal material for field preservation of leaf samples for DNA studies. Taxon 40:215-220.

3.Coates, D. and C.A. Cullis. 1987. Chloroplast DNA variability among Linum species. Am. J. Bot. 74:260-268.

4.Lehvaslaiho, H.A., A. Saura, and J. Lokki. 1987. Chloroplast DNA variation in the grass tribe Festuceae. Theor. Appl. Genet. 74:298301.

5.Liston, A., L. Reiseberg, R.P. Adams, M. Do, and G. Zhu. 1990. A method for collecting dried plant specimens for DNA and isozyme analyses, and the results of a field test in Xin-jiang, China. Ann. Missouri Bot. Gard. 77:859-863.

6.Reiseberg, L., D. Soltis, and J.D. Palmer. 1988. A molecular reexamination of introgression between Helianthus annuus and $\mathrm{H}$ bolanderi (Compositae). Evolution 42:227-238.

7.Doyle, J.J. and E.E. Dickson. 1987. Preservation if plant samples for DNA restriction en- donuclease analysis. Taxon 36:715-722

8.Pyle, M.M. and R.P. Adams. 1989. In situ preservation of DNA in plant specimens. Taxon 38:576-581.

9.Evans, W.C. 1981. The comparitive phytochemistry of the genus Erythroxylon. J. Ethnopharm. 3:265-277.

10.John, M.E. 1992. An efficient method for isolation of RNA and DNA from plants containing polyphenolics. Nucleic Acids Res 20:2381.

11.Katterman, F.R.H. and V.I. Shattuck. 1983 An effective method of DNA isolation from the mature leaves of Gossypium species that contain large amounts of phenolic terpenoids and tannins. Preparative Biochem. 13:347359.

12.Baker, S.B., C.L. Rugh, and J.C. Kamalay. 1990. RNA and DNA isolation from recalcitrant plant tissue. BioTechniques 9:268-272.

13.Ambion RNAlater ${ }^{\mathrm{TM}}$ manual. RNAlater ${ }^{\mathrm{TM}}$ (patent pending): Tissue Collection RNA Stabilization Solution. Ambion, Austin, TX.

14.Chirgwin, J.M., A.E. Przybyla, J.R. MacDonald, and W.J. Rutter. 1979. Isolation of biologically active ribonucleic acid from sources enriched in ribonuclease. Biochemistry 18:5294-5299.

15.Kim, C.S., C.H. Lee, J.S. Shin, Y.S. Chung, and N.I. Hyung. 1997. A simple and rapid method for isolation of high quality genomic DNA from fruit trees and conifers using PVP Nucleic Acids Res. 25:1085-1086.

16.Johnson, E.L., J.A. Saunders, S. Mischke, C.S. Helling, and S.D. Emche. Identification of Erythroxylum taxa by AFLP DNA analysis. Phytochem. (In press.)

17.Johnson, E.L. and C.D. Foy. 1996. Biomass accumulation and alkaloid content in leaves of Erythroxylum coca and Erythroxylum novogranatense var. novogranatense grown in soil with varying $\mathrm{pH}$. J. Plant Physiol. 149:444 450.

18.Vos, P., R. Hogers, M. Bleeker, M. Reijans, T. van de Lee, M. Hornes, A. Frijters, J. Pot, J., Peleman, et al. 1995. AFLP: a new technique for DNA fingerprinting. Nucleic Acids Res. 23:4407-4414.

19.Saunders, J.A., S. Mischke, and A.A. Hemeida. 2001a. The use of AFLP techniques for DNA fingerprinting in plants. Beckman Coulter Application Notes A1910A:1-9. Beckman Coulter, Fullerton, CA

20.Saunders, J.A., M.J. Pedroni, L.D.J. Penrose, and A.J. Fist. 2001b. AFLP DNA analysis of opium poppy. Crop Sci. 41:15961601 .

Received 2 December 2002; accepted 14 April 2003.

Address correspondence to Emanuel L. Johnson, USDA ARS Alternate Crops and Systems Laboratory, Bldg. 001 Rm. 329 BARC-W, 10300 Baltimore Ave., Beltsville, MD 20705-2350, USA. e-mail: johnsone @ba.ars.usda.gov 